\author{
بررسى ويزگى هاى فيزيكوشيميايى و رنگ ميوه برخى از نزادكانهاى \\ توت سفيد (Morus alba) در استان آذربايجان غربى \\ سامان فيروز باراندوزى' و حميد حسن يور”

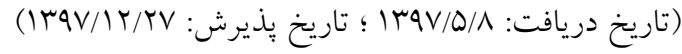

جִكيده

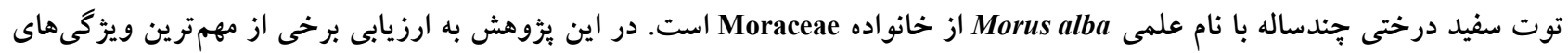

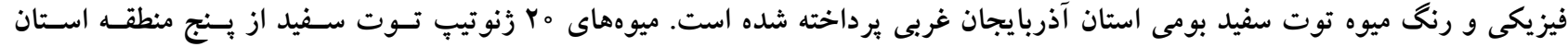

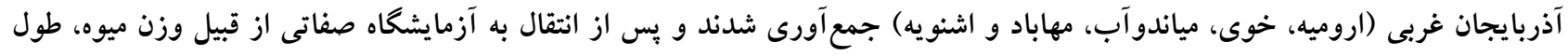

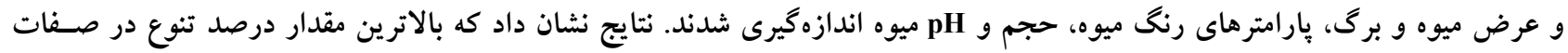

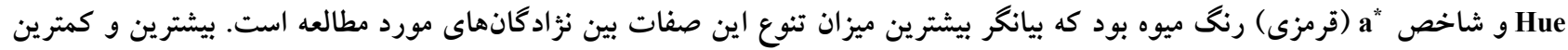

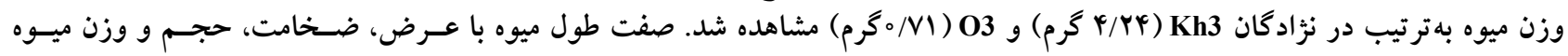

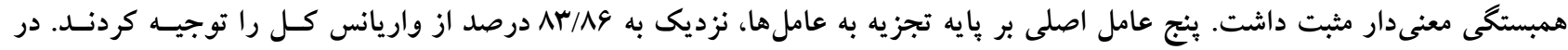

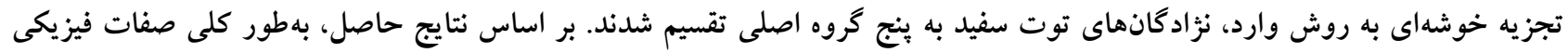

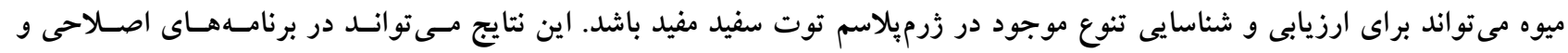

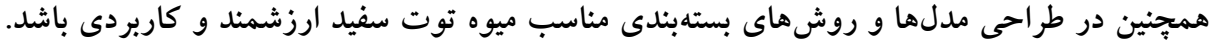

وازههاى كليدى: تجزيه كلاستر، حجم ميوه، صفات مورفولوزيكى، همبستحى 
آذربايجان غربى واقع شده است كه ميزان توليد اين محصول در

اين استان در حدود

تعيين ويزگى هاى فيزيكى ميوه محصولات باغى از مهمتردين

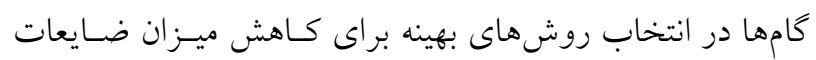

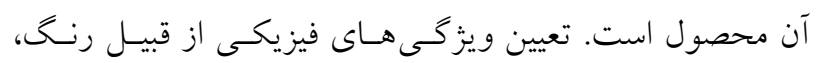

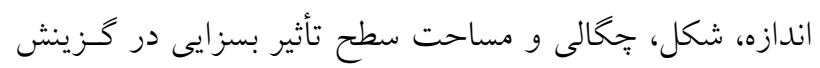

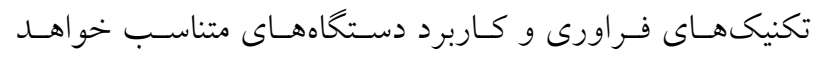
داشت. حملونقل صحيح و اصولى محصولات باغى يكى ديخر

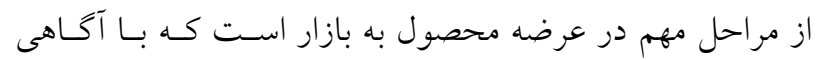

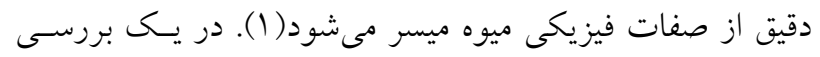

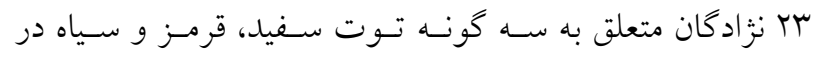
منطقه رجين تونس از نظرويزگى هاى ميوه ارزيـابى شــــ نتسايج

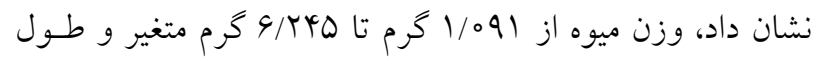

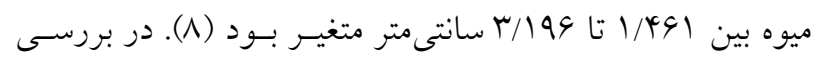

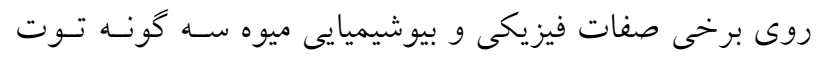

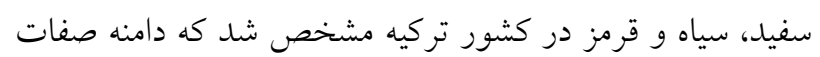

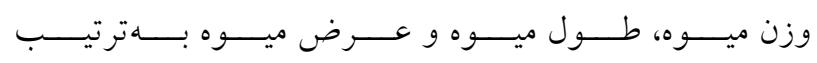

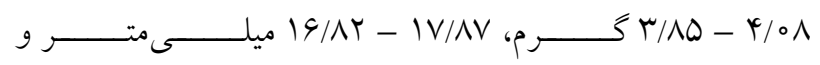

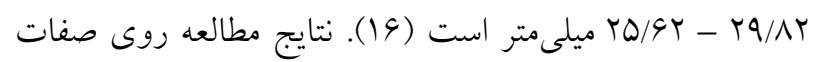

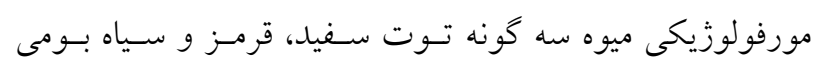

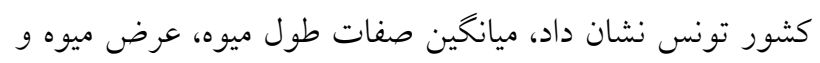

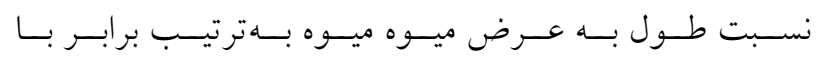

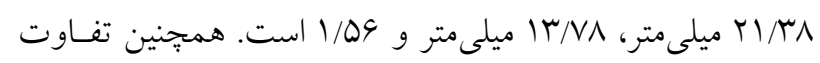

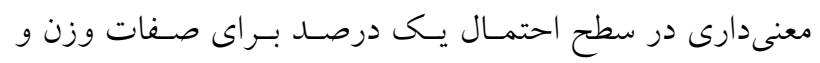

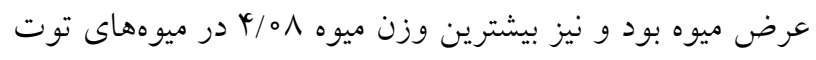
سياه مشاهده شد (r). در مطالعهاى ديخر كه روى سه كونسه تـوت سـفيد، قرمـز و و

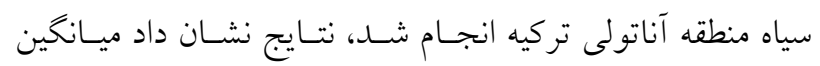

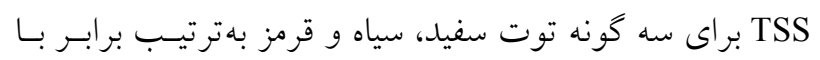

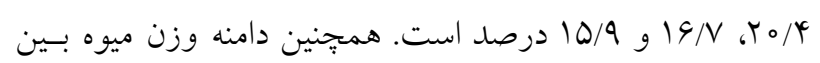

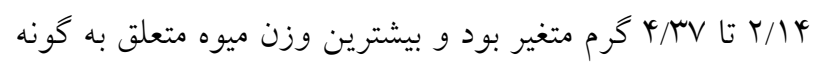

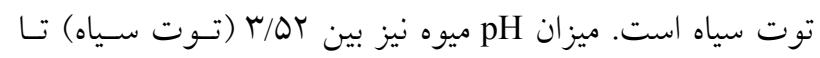

امروزه بيشتر مردم جهان ترجيح مىدهند در رزيم غــذايى خــود

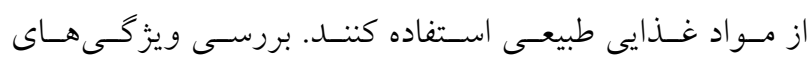

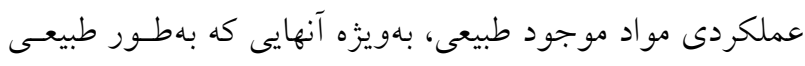

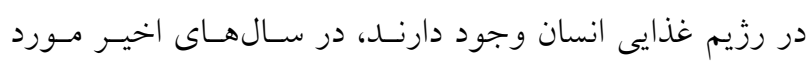

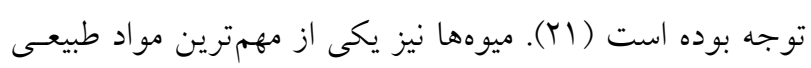

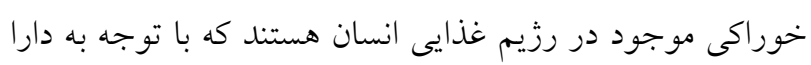

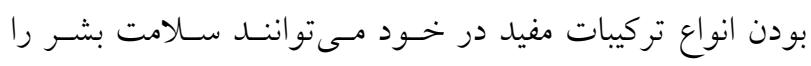

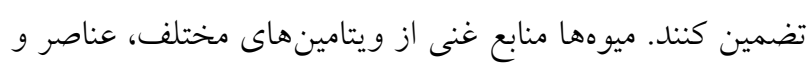

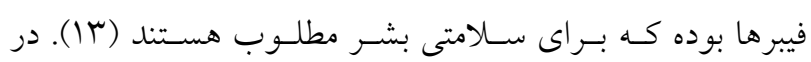

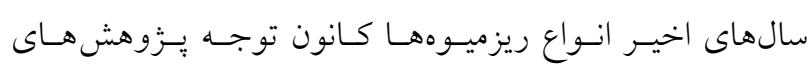

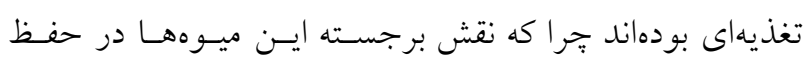

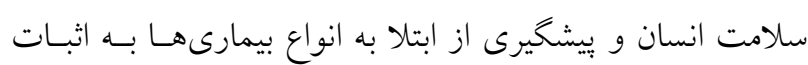
رسيده است (TY).

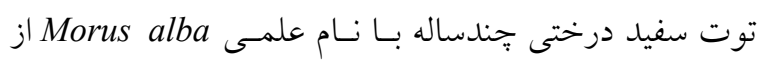

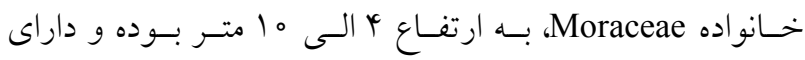

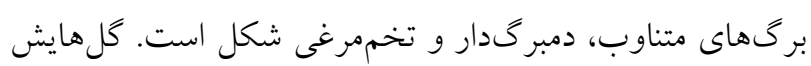

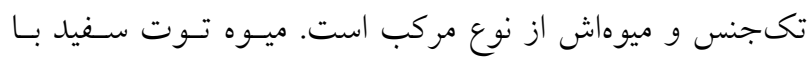

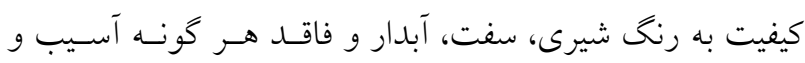

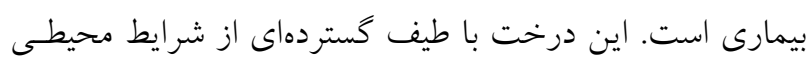

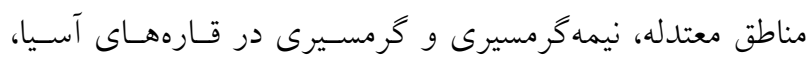

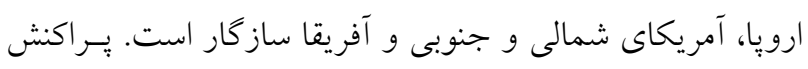
اين كونه در ايران محدود به اطراف تهـران، شـمال (مازنـدران،

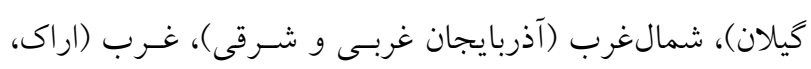

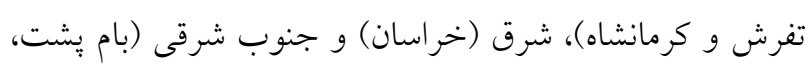

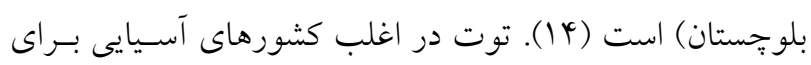

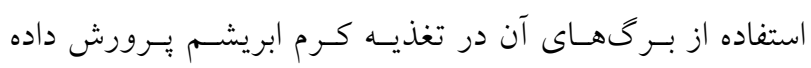

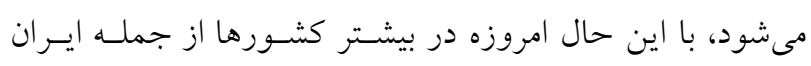

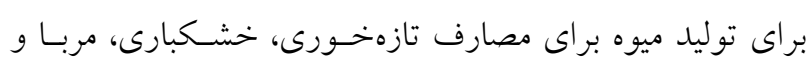

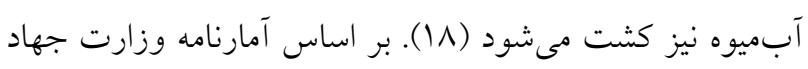

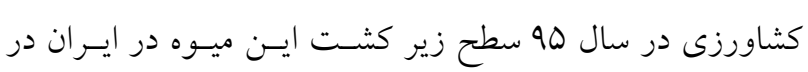

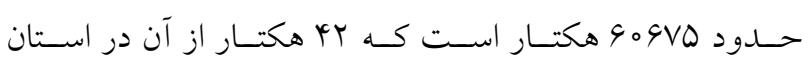




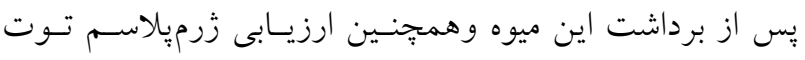

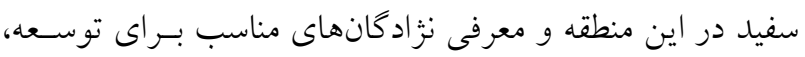
كشت و كار و استفاده از آن در برنامههاى اصلاحى است.

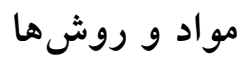

نحوه انتخاب و ارزيابى نمونهها

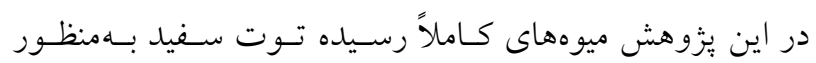

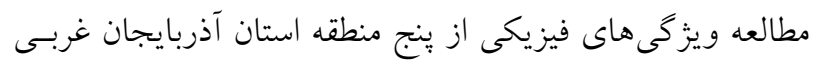

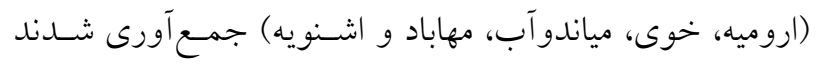

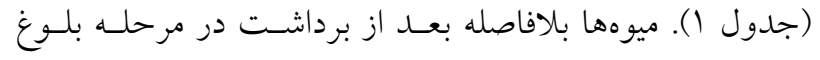

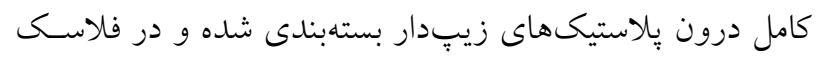

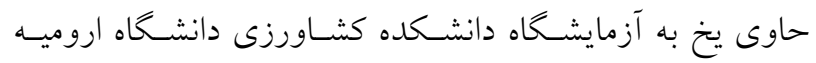

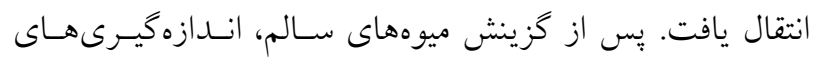

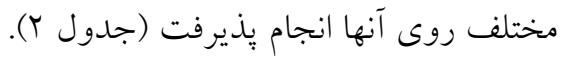

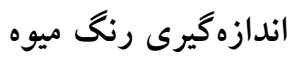

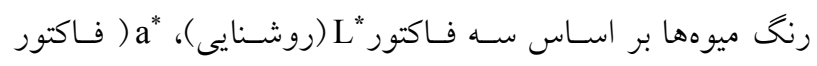

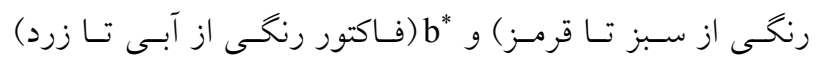

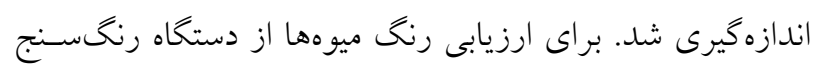

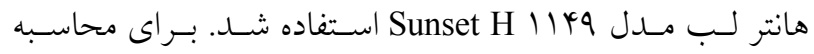

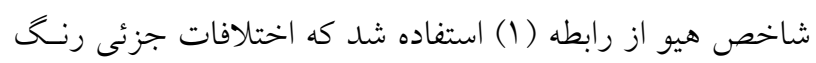

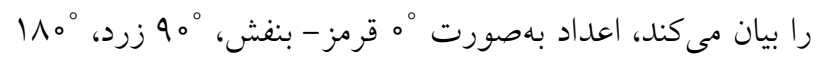

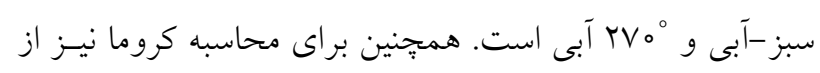

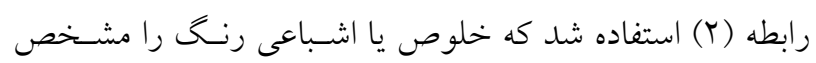

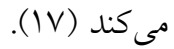

$\mathrm{Hue}=\arctan (\mathrm{b} / \mathrm{a})$

$C=\sqrt{a^{r}+b^{r}}$

\section{اندازهيرى ويزَّىهاى فيزيكى ميوه}

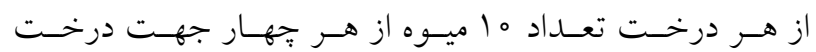
بهصورت تصادفى انتخاب و اندازهيرىهاى فيزيكى روى آنها

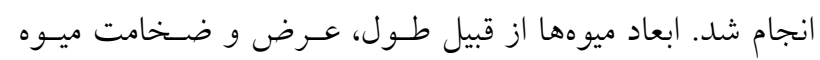

ه/9 (توت سفيد) متغير است (10). همجنين طى يزوهشى كـه با هدف بررسى تودههاى وحشى تمشـى سـياه در منـاطقى از

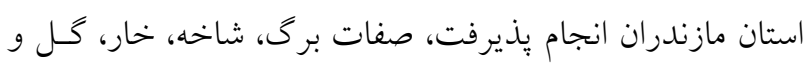

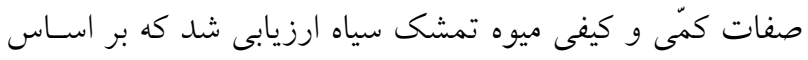

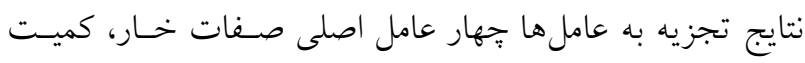

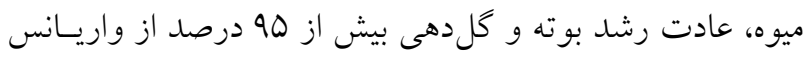

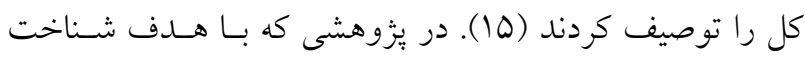

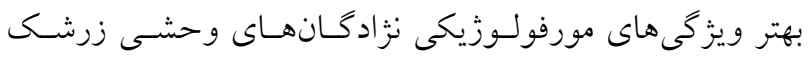

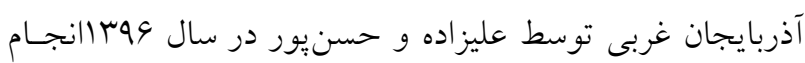

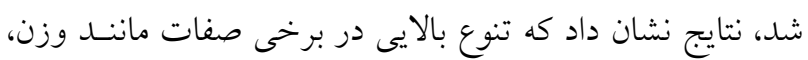

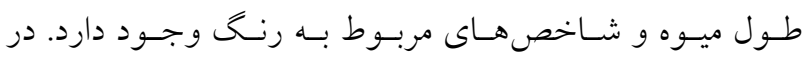

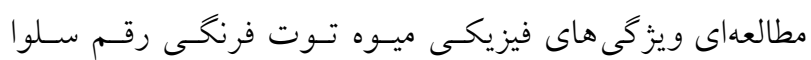

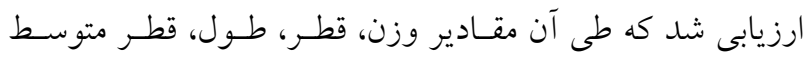

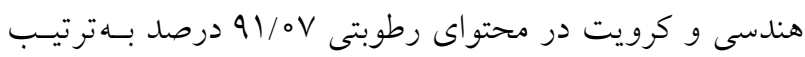

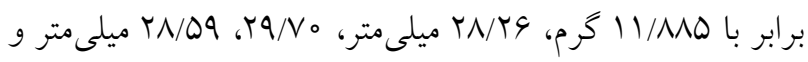

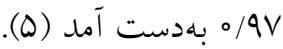

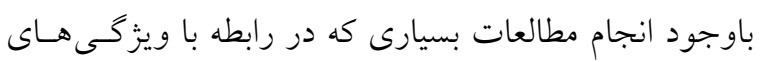

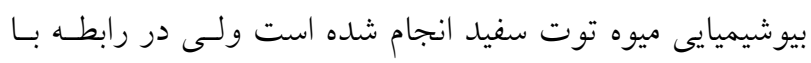

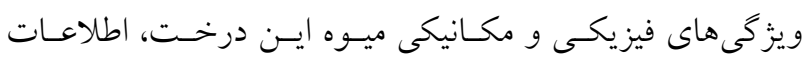
دقيقى در دسترس نيست، تكنيكهاى فراورى و حمل صـل صحيح

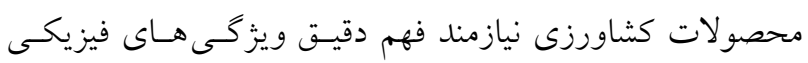

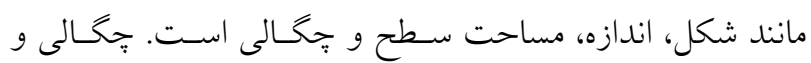

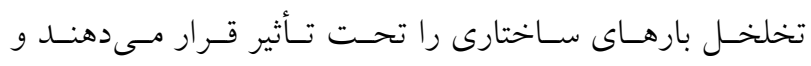

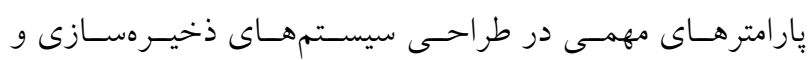

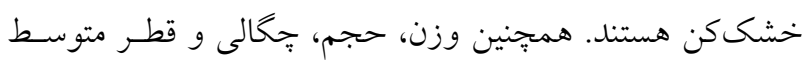

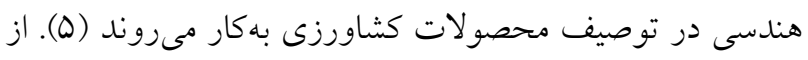
اينرو با توجه به وجود جمعيتهاى زياد از اين ميـوه در ايـران بلويزهه در منطقه شمال غـرب، انجـام ي-رزوهشهـاى بايسهاى در

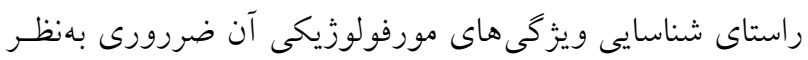

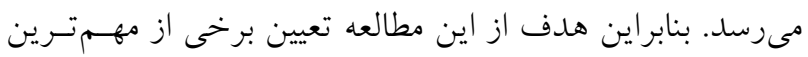

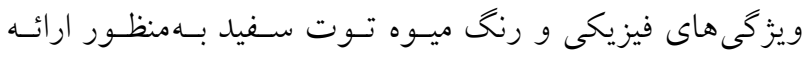
اطلاعات بايه براى انجام مطالعات تكميلى در زمينه برداشـت و و 
جدول ا. موقعيت جغرافيايى نزادگانهاى مورد مطالعه توت سفيد در استان آذربايجان غربى

\begin{tabular}{|c|c|c|c|c|}
\hline ارتفاع از سطح دريا & عرض جغرافيايى & طول جغر افيايى & محل جمع آورى نمونه & نز ادكًان \\
\hline 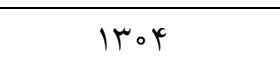 & $r V^{\circ} \mu^{\prime}$ & $r Q^{\circ} 1 r^{\prime}$ & اروميه & $\mathrm{UI}$ \\
\hline $1 r \circ r^{2}$ & $r V^{\circ} \mu_{l}$ & $r Q^{\circ} \mid r^{\prime}$ & اروميه & UT \\
\hline Iror & $r v^{\circ} \mu l^{\prime}$ & $r Q^{\circ} \mid r^{\prime}$ & اروميه & Ur \\
\hline $1 r \circ Y$ & $r V^{\circ} \mu^{\prime}$ & $40^{\circ} 1 r^{\prime}$ & اروميه - اريه & Ur \\
\hline Irro & ( & $\mu \psi^{\circ} \Delta r^{\prime}$ & 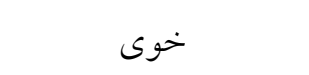 & $\mathrm{Khl}$ \\
\hline $1 r \circ 9$ & $\mu \Lambda^{\circ} \mu \mu^{\prime}$ & $\mu \psi^{\circ} \Delta r^{\prime}$ & خوى & Khr \\
\hline ITOY & $r \Lambda^{\circ} r \omega^{\prime}$ & $\mu \mu^{\circ} 0_{0}^{\prime}$ & خوى & $\mathrm{Kh} r$ \\
\hline Iror & $r \Lambda^{\circ} r \boldsymbol{o}^{\prime}$ & $k 4^{\circ} 0^{\prime}$ & 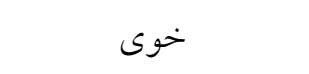 & Khy \\
\hline$|r q|$ & $r v^{\circ} \cdot l^{\prime}$ & $14^{\circ} \circ 9^{\prime}$ & مياندوآب & $\mathrm{Mn})$ \\
\hline $1 \% 10$ & $r \varphi^{\circ} \Delta q^{\prime}$ & $19^{\circ} \circ D^{\prime}$ & مياندوآب & Mnr \\
\hline 1519 & $r q^{\circ} \Delta q^{\prime}$ & $4 \varphi^{\circ} \circ D^{\prime}$ & مياندوآب & $\mathrm{Mnr}$ \\
\hline ITYT & $r q^{\circ} \Delta q^{\prime}$ & $49^{\circ} \circ D^{\prime}$ & مياندوآب & Mnt \\
\hline ITTV & $r \varphi^{\circ} \Delta I^{\prime}$ & $Y Q^{\circ} Y Y^{\prime}$ & 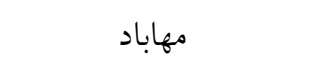 & $\mathrm{Mal}$ \\
\hline Irko & $r \varphi^{\circ} r \varphi^{\prime}$ & $Y Q^{\circ} Y Y^{\prime}$ & 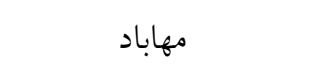 & Mar \\
\hline IrTa & $r \varphi^{\circ} D_{0}^{\prime}$ & $Y Q^{\circ} Y Q^{\prime}$ & 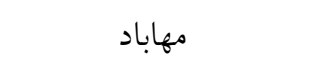 & $\mathrm{Mar}$ \\
\hline $\mid r \circ \Lambda$ & $r \varphi^{\circ} D_{0}^{\prime}$ & $Y Q^{\circ} Y 0^{\prime}$ & 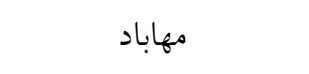 & Mar \\
\hline lert & $r V^{0} \circ D^{\prime}$ & $r \Delta^{\circ} \circ \varphi^{\prime}$ & اشنويه & OI \\
\hline lkro & $r V^{0} \circ r^{\prime}$ & $r D^{\circ} \circ \varphi^{\prime}$ & اشنويه & Or \\
\hline$|\mathrm{kr}|$ & $r V^{0} \circ r^{\prime}$ & $r D^{\circ} \circ \varphi^{\prime}$ & اشنويه & Or \\
\hline IKYA & $r v^{0} \circ r^{\prime}$ & $40^{\circ} \circ 9^{\prime}$ & اشنويه & Or \\
\hline
\end{tabular}

$$
\begin{aligned}
& \mathrm{AR}=(\mathrm{W} / \mathrm{L}) \times 100 \\
& \mathrm{~V}=\pi \times \mathrm{dg}^{\Gamma} / \varsigma \\
& \rho b=\frac{m}{v} \\
& \text { (L) طول ميوه، (W): عرض ميوه و (V): حجم ميوه است. }
\end{aligned}
$$

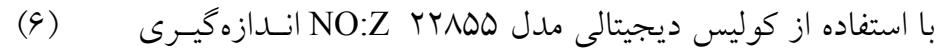

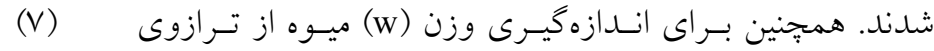

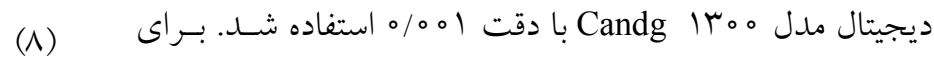

مواد جامد محلول كل (TSS)، اسيديته قابل تيتراسيون (TA)

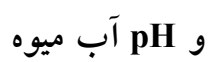

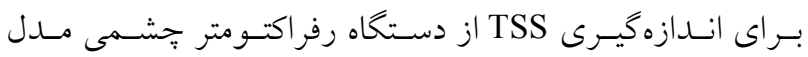

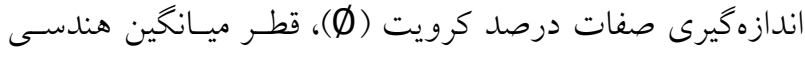

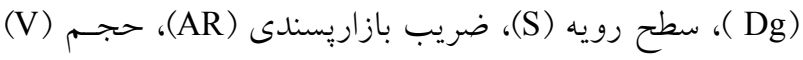

و جحالى ميوه (bp) بهترتيب از رابطههاى زير استفاده شد (9):

$\emptyset=(\operatorname{Dg} / \mathrm{L}) \times 10 \circ$

$\mathrm{Dg}=(\mathrm{LW} r) \circ \mu \mathrm{r}$

$\mathrm{S}=\pi(\mathrm{Dg})^{r}$ 
جدول r. صفات ارزيابىشده و واحد اندازهيرى آنها در نزادگانهاى مورد بررسى

\begin{tabular}{|c|c|c|c|c|c|c|c|}
\hline واحد & مخفف & نام صفت & رديف & واحد & مخفف & نام صفت & رديف \\
\hline- & $\mathrm{L}^{*}$ & $\mathrm{~L}^{*}$ & $1 r$ & $(\mathrm{~mm})$ & FL & طول ميوه & 1 \\
\hline- & $a^{*}$ & $a^{*}$ & 14 & $(\mathrm{~mm})$ & FW & عرض ميوه & r \\
\hline- & $b^{*}$ & $b^{*}$ & 10 & $(\mathrm{~mm})$ & FT & ضخامت ميوه & r \\
\hline- & $\mathrm{C}$ & Chroma & 19 & $(\mathrm{~mm})$ & FP & طول دم ميوه & $r$ \\
\hline- & $\mathrm{h}$ & Hue & IV & - & FLFW & نسبت طول به عرض ميوه & 0 \\
\hline $\mathrm{g}$ & FWe & وزن ميوه & 11 & $(\mathrm{~mm})$ & $\mathrm{Dg}$ & قطر ميانخين هندسى & 9 \\
\hline$(\%)$ & TA & اسيديته قابل تيتراسيون & 19 & $(\%)$ & $\varnothing$ & كرويت هندسى & V \\
\hline درجه بريكس & TSS & مواد جامد محلول & ro & $\left(\mathrm{cm}^{r}\right)$ & $\mathrm{V}$ & حجم & $\wedge$ \\
\hline$\left(\mathrm{mm}^{r}\right)$ & $\mathrm{S}$ & مساحت سطح رويه & YI & $\left(\mathrm{g} / \mathrm{cm}^{r}\right)$ & $\mathrm{D}$ & جَالى حقيقى & 9 \\
\hline- & $\mathrm{pH}$ & $\mathrm{pH}$ & Tr & $(\mathrm{cm})$ & LL & طول برى & 10 \\
\hline \multirow[t]{2}{*}{-} & $\mathrm{AR}$ & ضريب بازاريسندى & r & $(\mathrm{cm})$ & LW & عرض برى & 11 \\
\hline & & & & $(\mathrm{cm})$ & $\mathrm{P}$ & طول دمبرى & ir \\
\hline
\end{tabular}

شد. يس از اندازه گيرى صـفات مــنظر، بـراى محاسـبه تجزيـه واريانس، انحراف معيار، تجزيه بـه عامـل و تجزيـه همبسـتخى صفات از نرمافزار SPSS نسخه 19 استفاده شد. همجنين تجزيه خوشهاى دادهها نيز بر اساس روش وارد و بـهـوسـيله نــرمافـزار SPSS

\section{نتايج و بحث} آمار توصيفى صفات

بر اساس نتايج آمار توصيفى صفات مورفولـوزيكى ميـوه و بـرك توت (جدول r) معلوم شد كه بالاترين درصـد تنـوع مربـوط بـه صفت a* رنغ بوده كه بيانخر بيشترين ميزان تنوع اين صفت بـين نزادكانهاى مورد مطالعه است. با توجه به اينكه در كشـور ايسران مطالعات بهنزادى جنـانى روى زنوتيبها و ارقام تـوت صـورت نخرفته است، از اينرو شايد تنوع صـفات ميسوه بررسسى شــده در ميان زنوتيِهاى مختلف به اين دليـل نسـبتاً يـايين بـوده اسـت.

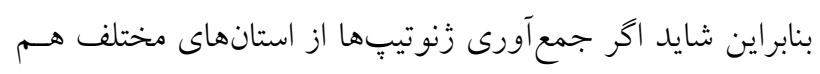
صورت مى گرفت، تنوع صفات مىتوانست بيشتر از اين باشد. بـا

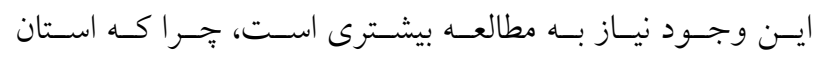

ساخت زاين با دامنه •Y- Atago-ATC-Y॰E شد. به اين ترتيب كه يك قطـره از عصـاره ميـوه روى دســاه قرار داده و درصد مواد جامد محلول قرائـت و ثبـت شــ (1Y).

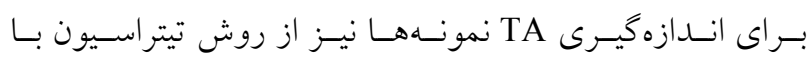
هيدروكسيد سديم (NaOH) / /ه نرمال (جهار كرم در ليتـر) تـا استفاده شـد. بـر اسـاس ميـزان هيدرواكسـيد ســـيم pH =N/1 مصرفى طى عمل تيتراسيون، مقدار اسيد موجود در عصاره ميوه با استفاده از فرمول زير به صورت درصد بيان شد (سا). $\mathrm{TA}=\mathrm{TA}=\left(\frac{\mathrm{S} \times \mathrm{N} \times \mathrm{F} \times \mathrm{E}}{\mathrm{C}}\right) \times 1$ 。 (مقدار اسيديته قابل تيتراسيون)، SA $\mathrm{S}$ (مقدار NaOH مصـرف

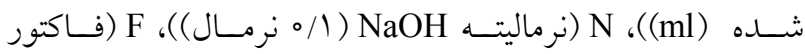

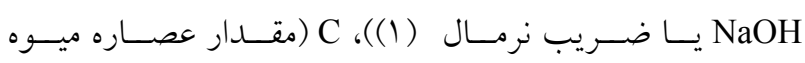
( ا ميلىليتر))، E (اكى الان اسيد غالب ميوه (اسيد سيتريك)). همجنين pH ميوهها با استفاده از دستخاه pH متر ديجيتالى مـدل

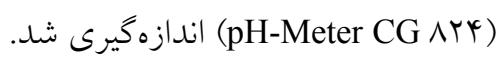

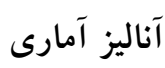
اين يُزوهش در قالب طرح كاملاً تصادفى و در سه تكرار انجـام 
جدول r. آمارتوصيفى صفات اندازهيرىشده در نزادگانهاى مورد مطالعه توت

\begin{tabular}{|c|c|c|c|c|c|}
\hline درصد تنوع & انحراف معيار & بيشترين & كمترين & ميانخين & صفات \\
\hline $\mid N / 4 F$ & $\varphi / 01$ & $r q / 9$ & $\mid \varphi / \varphi \wedge$ & YI/VY & FL (mm) \\
\hline N/VT & $1 / 1$ & $10 / 00$ & $10 / 4 q$ & $|T / 9|$ & $\mathrm{FW}(\mathrm{mm})$ \\
\hline $1 / 90$ & $1 / 11$ & $10 / 4 T$ & $10 / 0 \mu$ & IT/AK & FT (mm) \\
\hline $1 \Lambda / V$ & $1 / 91$ & $|Y / V|$ & $4 / 90$ & $1 / 9 \Lambda$ & $\mathrm{FP}(\mathrm{mm})$ \\
\hline $10 / 99$ & $0 / T V$ & $r / \mathcal{T}$ & $1 / T V$ & $1 / V T$ & FLFW \\
\hline $1 V / O Y$ & $1 / V 1$ & $1 \pi / 0$ & $Q / \Lambda$ & $10 / 0 r$ & $\mathrm{LL}(\mathrm{cm})$ \\
\hline $19 / T Y$ & $1 / 4$ & $10 / \mu$ & $\varphi / r$ & V/A & LW (cm) \\
\hline m/vV & $1 / 0 r$ & $N / 9 V$ & $r / \Delta$ & $r / \Delta r$ & $\mathrm{P}(\mathrm{cm})$ \\
\hline$|9 / 4|$ & $Q / \wedge \Delta$ & $1 Y / 19$ & $41 / \Delta r$ & $90 / 01$ & $\mathrm{AR}$ \\
\hline$\mu_{\circ / 9 \Lambda}$ & $\circ / \Delta \Lambda$ & $r / 11$ & ०/AK & $1 / 19$ & $\mathrm{~V}\left(\mathrm{~cm}^{r}\right)$ \\
\hline$M \Psi / \varphi \wedge$ & $\circ / V$ & $Y / Y Y$ & $\circ / \mathrm{VI}$ & $r / \circ{ }^{2}$ & Few (g) \\
\hline $9 / 01$ & $Q / \circ D$ & $9 \mathrm{~V} / 0 \mathrm{~V}$ & $4 r / \wedge q$ & $\Delta \Delta / 99$ & $\mathrm{~L}^{*}$ \\
\hline$\Delta \& / 0 \wedge$ & $1 / 79$ & س & $-Y / \Lambda Y$ & $-T / \Gamma$ & $a^{*}$ \\
\hline $14 / 91$ & $\Gamma / 1 \Lambda$ & $19 / 0 r$ & $10 / 4 x$ & $1 Y / 9 T$ & $b^{*}$ \\
\hline $14 / 9 r$ & $T / Y G$ & $19 / 94$ & $10 / 40$ & $10 /\left.1\right|^{4}$ & $\mathrm{C}$ \\
\hline YI/TY & $\circ / Q T$ & $1 / 09$ & $-1 / 09$ & $-|/ \mu|$ & $\mathrm{h}$ \\
\hline$r q / 0$ & $r / \Delta \varphi$ & rA & $0 / 19$ & $0 / 9$ & TA $(\%)$ \\
\hline YY/QG & $r / 91$ & TY & Q/AV & $10 / V T$ & TSS (Brix) \\
\hline$r \circ / \wedge D$ & $1 / 0 Y$ & $10 / 49$ & $Y / T V$ & $V / r q$ & $\mathrm{~S}\left(\mathrm{~mm}^{r}\right)$ \\
\hline $9 / \mathrm{V}$ & G/AV & $\Lambda \Delta / \uparrow \varphi$ & $\Delta V / T I$ & $V \circ / v q$ & $\varnothing(\%)$ \\
\hline $11 / 0$ &.$/ 09$ & $9 / 41$ & $r$ & $0 / 1 \pi$ & $\mathrm{pH}$ \\
\hline $10 / 0 V$ & $1 / 9$ & $1 N / \circ r$ & $11 / 99$ & $10 / 11$ & $\mathrm{Dg}(\mathrm{mm})$ \\
\hline$T V / T V$ & \% r & $O / Y Y$ & $0 / 09$ & $0 / 11$ & $\mathrm{D}\left(\mathrm{g} / \mathrm{cm}^{r}\right)$ \\
\hline
\end{tabular}

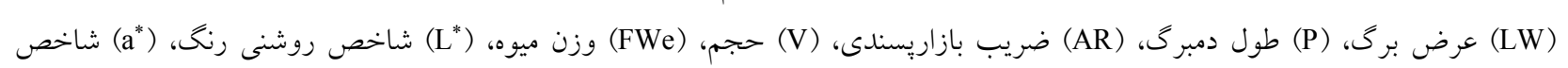

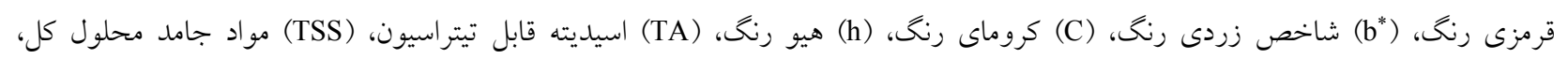

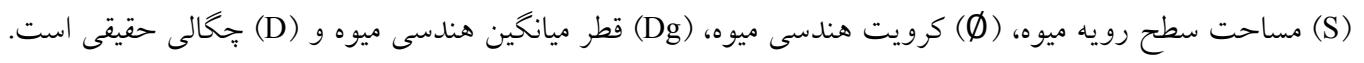

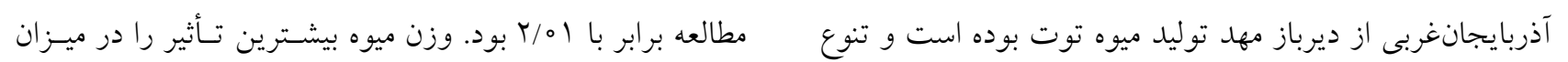

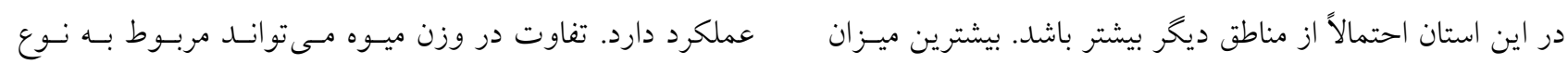

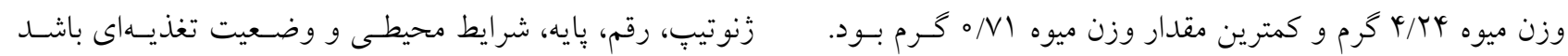

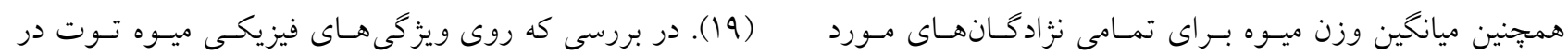


ابعاد، حجم و جخمالى محصـولات كشــاورزى عـلاوهبـر تعيسين

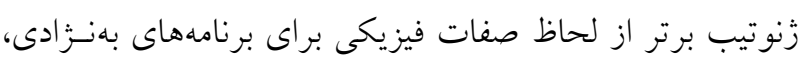

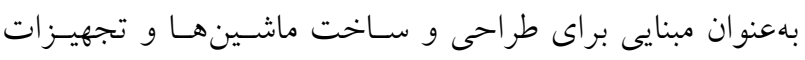

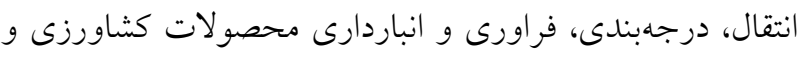

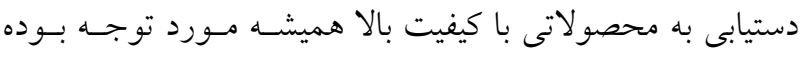

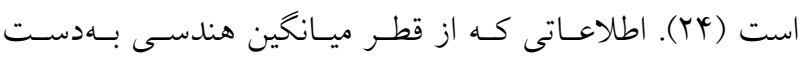

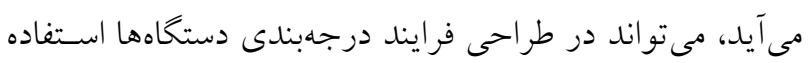

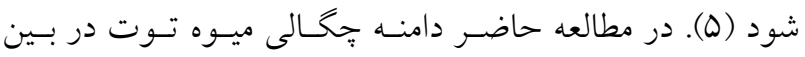

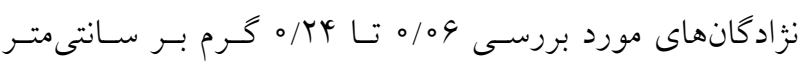

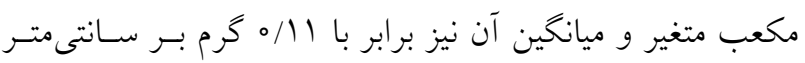

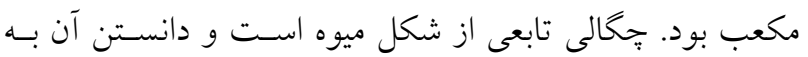

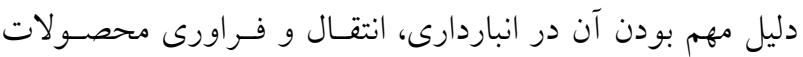
كشاورزى ضرورى اسـت. جـــا كـه روشهـاى تميـز كـردن و

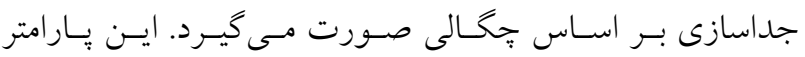
همجنين در تعيين ابعاد انبار نيز كاربرد فراوانى دارد، همجنـين

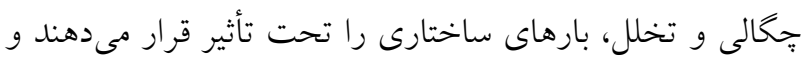

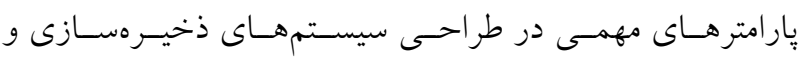

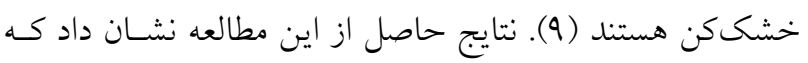

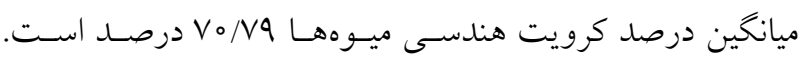

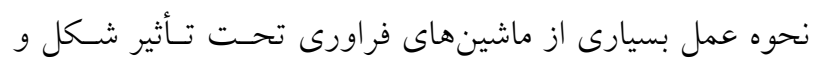

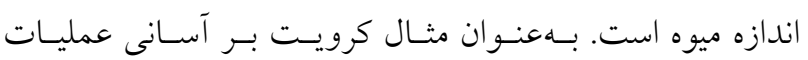

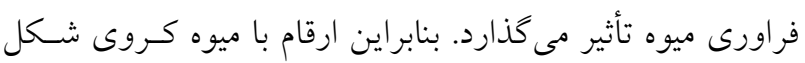

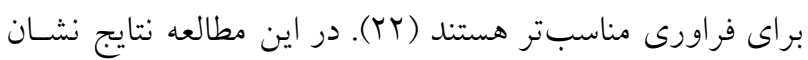

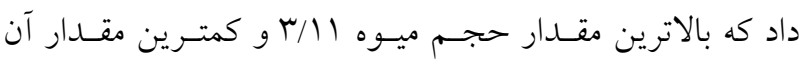

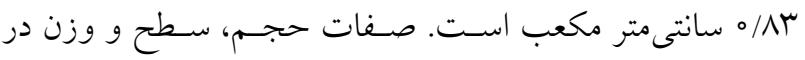

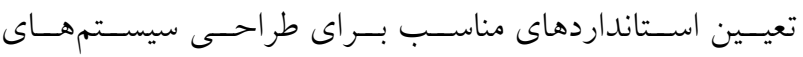

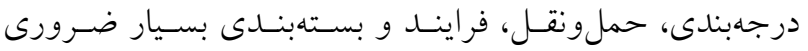
هستند (Q). بهطور كلى ويزگى هاى فيزيكى و مكانيكى ميـوهــا

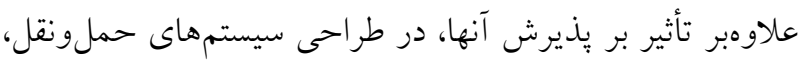
بستهبندى و ذخيرهسازى اهميت زيادى دارد. بهمنظور ييدا كردن بهترين روش برداشت، جابهجايى، انباردارى، حملونقل، مطالعه ويزگ هاى فيزيكى و مكانيكى ميوهها يكى امر ضـرورى اسـت.
تركيه انجام شده است، نتايج نشـان داد كـه ميـانخين وزن ميـوه براى توت سفيد (M. alba)

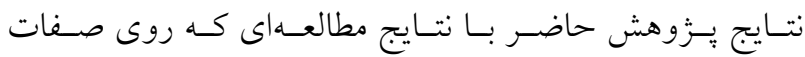
مورفولوزيكى ب بز نزادكان از سه كونه تسوت سفيد (M. alba)، توت قرمز (M. rubra) و تو توت سـياه (Migra) بـومى تركيـه

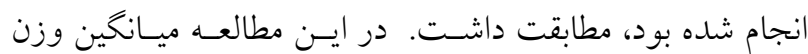

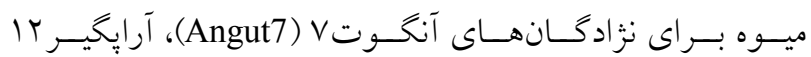
(Arapgir12)

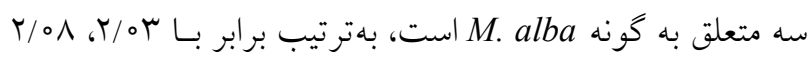

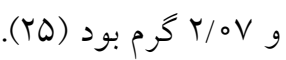

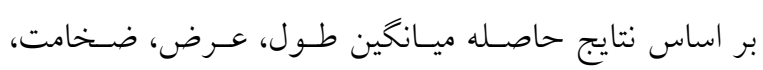

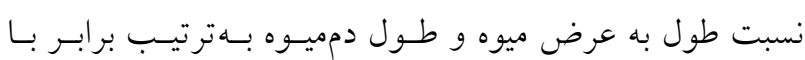

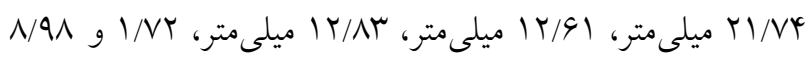

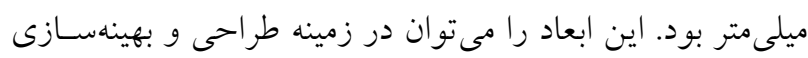

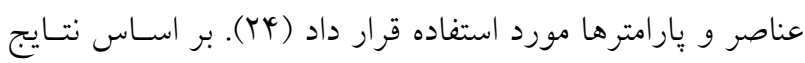

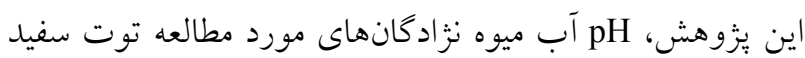

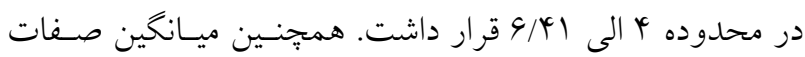
ضريب بازاريسندى، مساحت سطح رويه و قطر متوسط هندسى

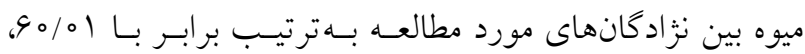

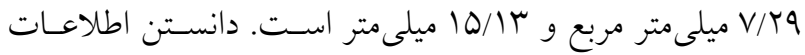
مرتبط با قطر ميانكبن هندسى در طراحسى فراينـد درجسهبندى

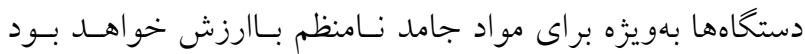
(D). در مطالعه انجام گرفتسه روى تـوتفرنغسى رقـم كردستـان

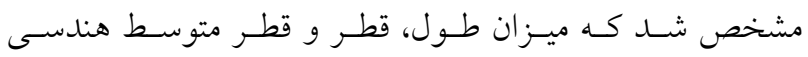

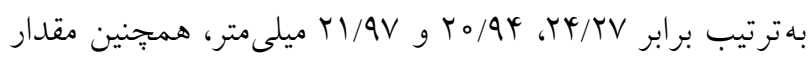

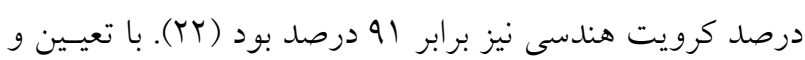

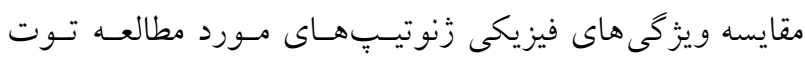
مشخص شد كه تنوع ويزَكى هاى فيزيكى در نز ادكَانهـا نسـبتاً

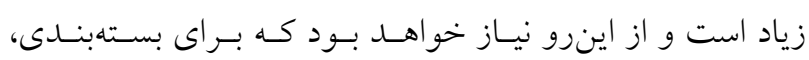

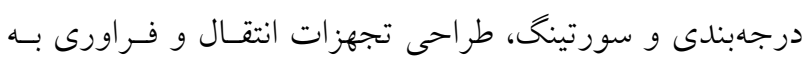

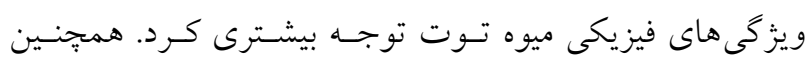

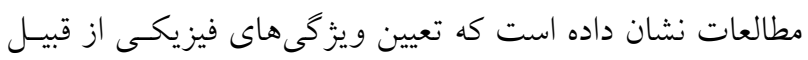


رقم بخارا داراى بيشترين مقـادير در شـاخصهـاى

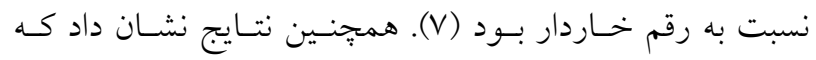

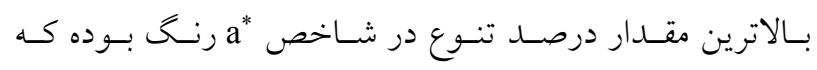

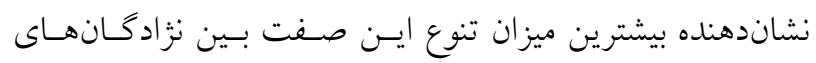

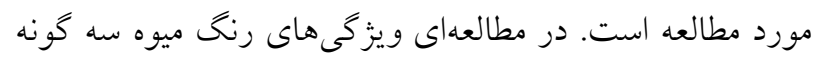
توت سفيد (M. alba)، توت قرمـز (M. rubra) و تـوت سـياه رشد يافته در شرق منطقه آنـاتولى تركيـه بررسىى (M. nigra)

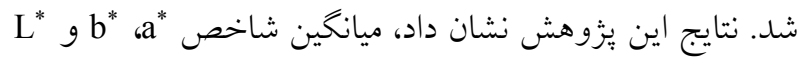

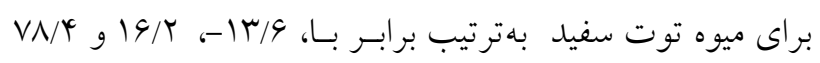

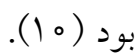

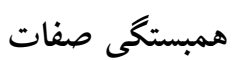

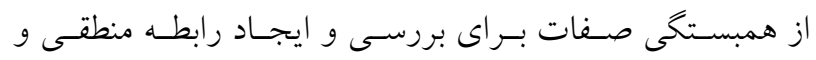

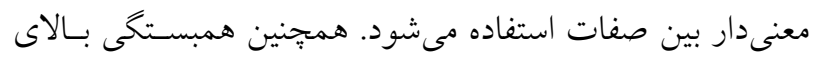

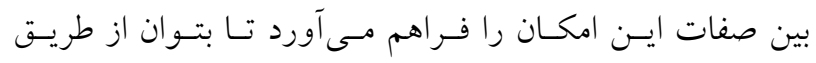

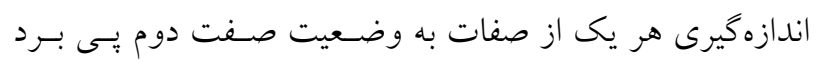

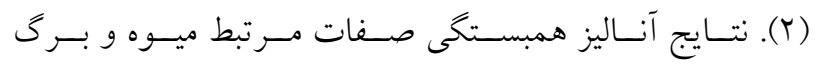

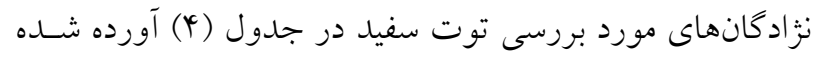

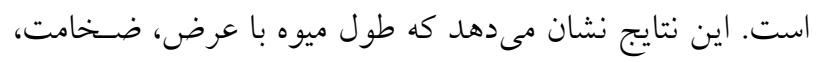

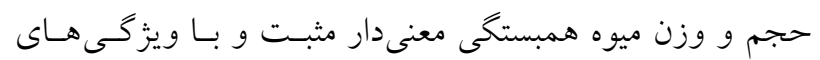

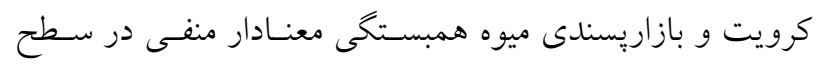
احتمال يك درصد دارد. عرض ميوه با ضخامت و حجـم ميـوه

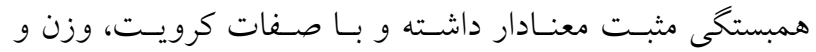

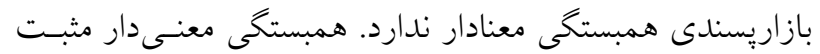

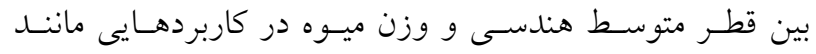

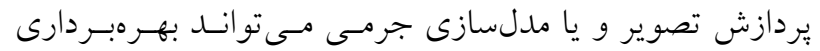
شود. مدلسـازى جرمسى محصـولات كشـاورزى از روشهـاى معمول اسـت كـه در اهــاف طراحسى اسـتفاده مسى شـود (YY). همانطور كه مشاهده مىشود صفت وزن ميوه بـا صـفات طـول

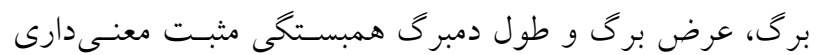

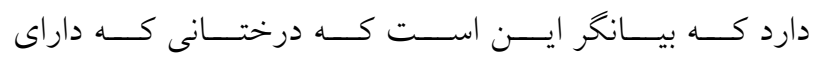

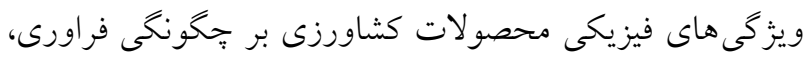

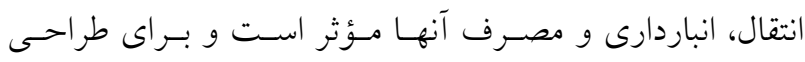

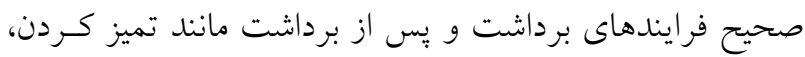
حمل ونقل و ذخيرهسازى به آنها نياز است (YY)

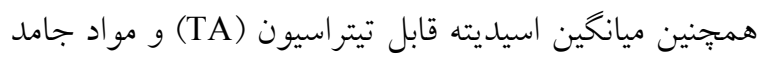

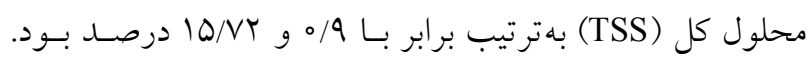

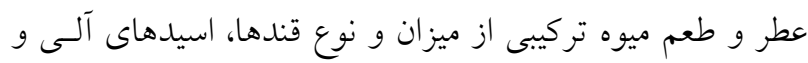

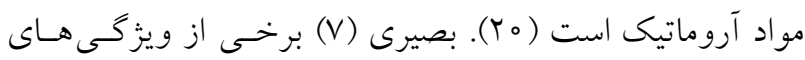
فيزيكوشيميايى دو رقم توت سفيد با نامهاى بخارا و خاردار كه

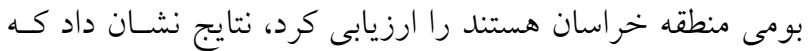

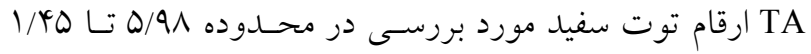
درصد متغير بود. همجنِين ميزان pH براى رقم بخـارا و خـاردار بهت ترتيب برابر با 9/01 و 9/Nه بود. دامنه اندازه طول- دمبرگ از

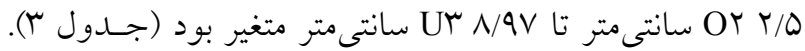

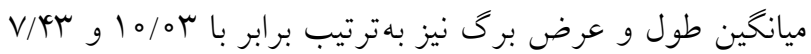
سانتى متر بود.

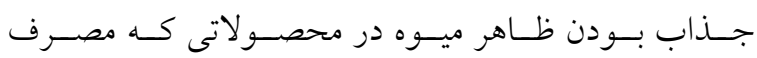

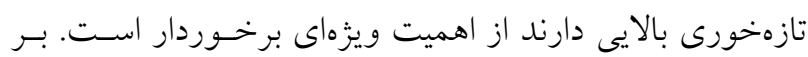

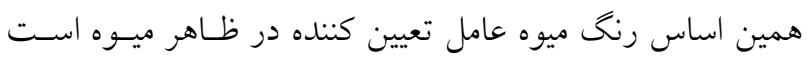

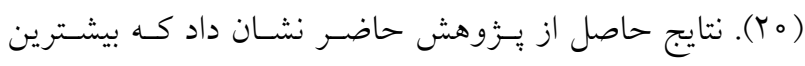

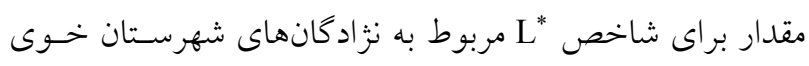
بوده كه نشان از شفافيت بالاى ميوهها در اين منطقه دارد. ميـزان

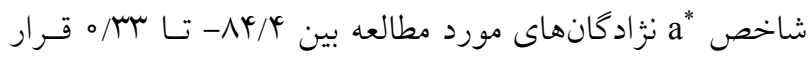

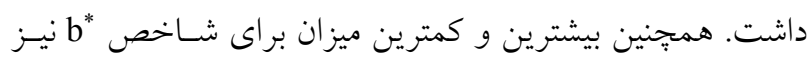

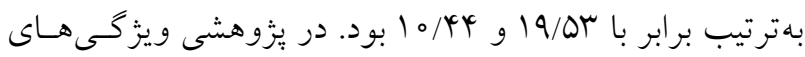

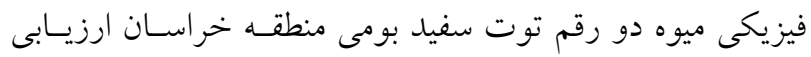

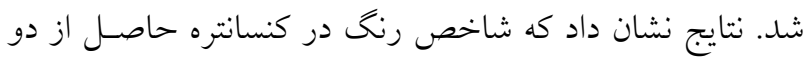
رقم توت سـفيد يـاد شـــه اخـتلاف معنــادارى بــا هـم دارنـــــ كنسانترههاى بهدست آمده از توت بخارا بيشترين ميزان شفافيت را داشت. ميـزان سـبزى / قرمـزى محصـولات در (L" =IV/VN)

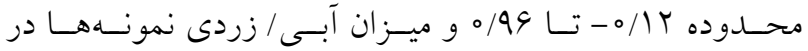
محدوده ץא/ه تا •T/ بودند. همجِنين كنسانتره بهدست آمده از 


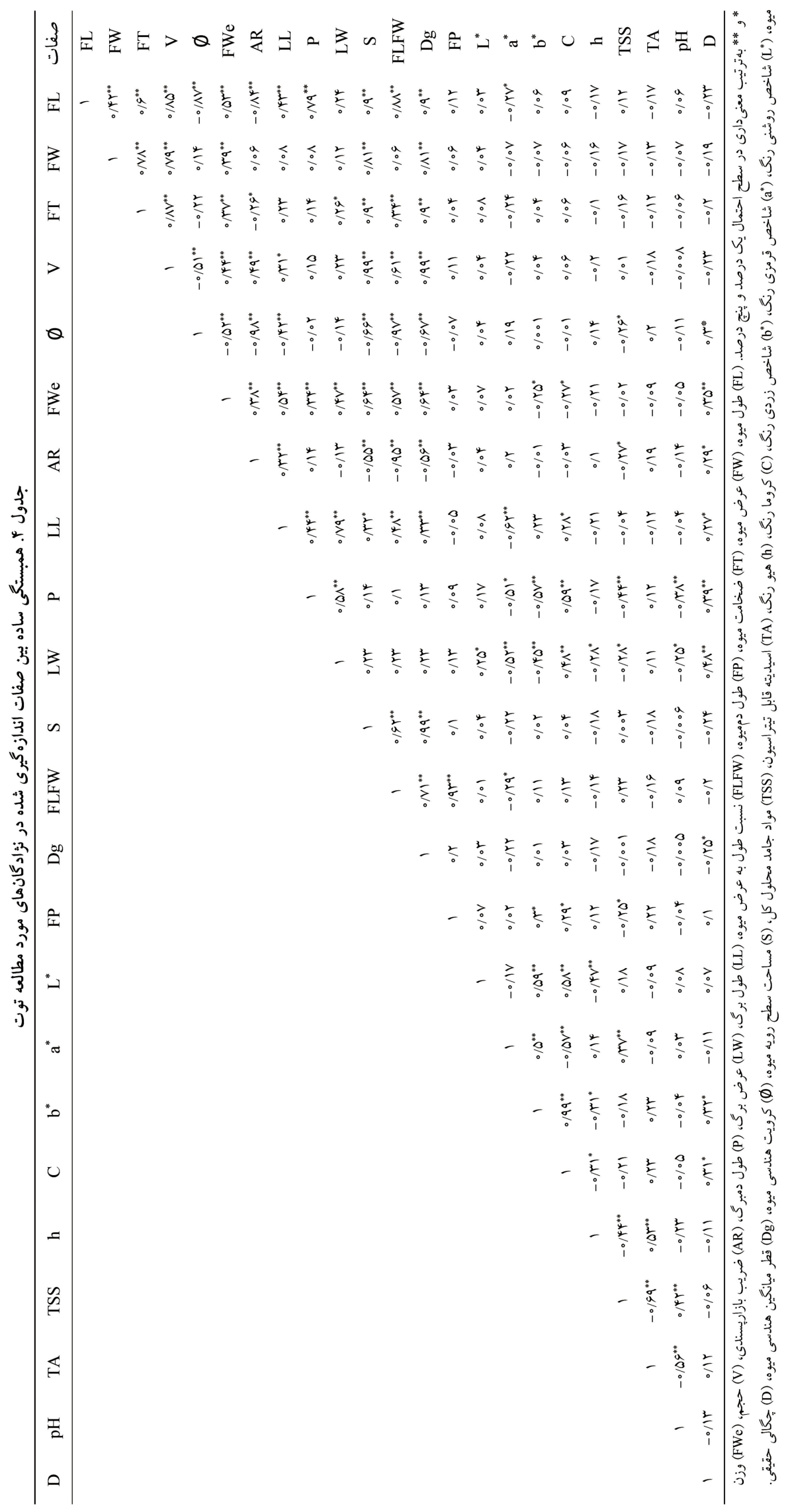


عامـلهــاى مسـتقل بــراى هــــــــروه از صـفات مسى توانــــ در برنامههاى اصلاحى مورد توجه قرار كرفته و به استقلال صفات

توجه شود (r) (r) (r)

\section{تجزيه كلاستر}

كروهبندى نزاد كانها بر اساس صفات مختلـف مسىتوانـد روشىى مــؤثر در مشـخص شـــن رابطـه نز ادخــانهــا و تعيـين فاصـله خويشاوندى آنها باشد. خوشهبندى صفات بر اساس تعـداد زيـاد صفات مىتواند روش مطمئنى در تعيين شباهتها و فواصل بـين نزادكانها باشد (4) با توجه به نتـايج تجزيسه كاسـتر (شـكل ()

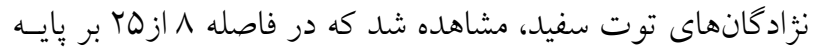
تجزيه تابع تشخيص، نزادگانهاى مـورد مطالعـه در يـنج خوشـه قرار كرفتهاند. در خوشه اول، هفت نزادگان قرار كرفـت كـهـهـ هـر جهار نز ادكان شهرستان اروميه، نزادكان Kh) شهرسـتان خـوى و نزادكانهاى Mar و Mar شهرستان مهابـاد در ايسن خوشـه قـرار كرفتند. قرار گيرى نزادگانهاى مربوط به شهرستان اروميه در كنـار

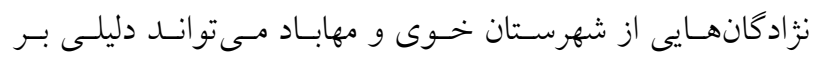
جابهجايى زرميلاسم اطـلاق شـود. نزادخـانهـاى ايسن خوشـهـ از بالاترين مقدار ميانخين عرض و ضخامت ميوه و نيـز زبـايينتسرين

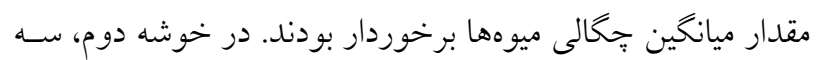

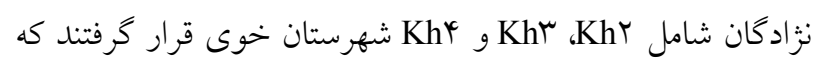
اين نزاد گانها از بالاترين ميانخين صفات طول برگ، عرض برگ، سطح رويه ميوه، حجم ميوه، قطر متوسط هندسىى، طـول ميـوه و وزن ميوه برخوردار بودند. هر سه نزادكان قرار كرفتسه در خوشـه سوم متعلـق بـه شهرسـتان ميانـدوآب بـود و در خوشـه جهـارم،

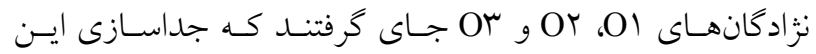
نمونهها با منشأ جغر افيايى آن مطابقت داشت. همجينين شهرسـان اشنويه به لحاظ ارتفاع از سطح دريا در بالاترين سطح نسبت بـه

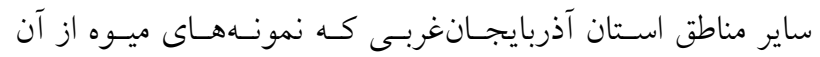

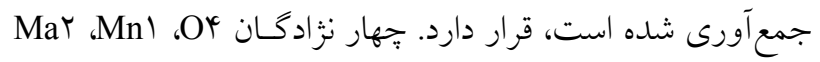
و Mal نيز در خوشه بنجم دستهبندى شـدند. صـفات مـرتبط بـا شاخصهاى رنخ ميوه و همجينين صفت TA ميوه در جداسـازى نزادكانهاى اين خوشه تأثير كذار بودهاند. بررسى تنوع زنتيكسى بـا

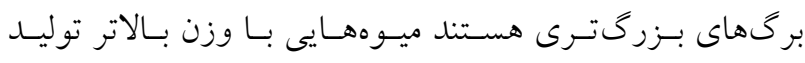
مى كنند. نتايج بهدست آمده مطابق با نتايج حاصل از بررسىهاى لَّل

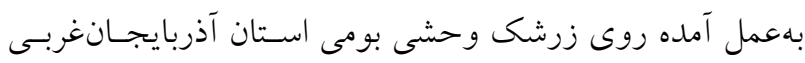

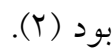

\section{تجزيه به عامل ها}

با استفاده از تجزيه عاملى، صفات مختلف مسىتوانــد در قالـب

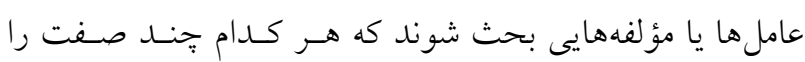

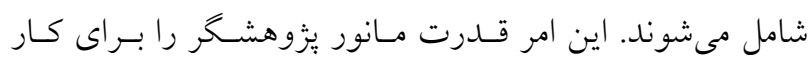
روى تعداد عامل يا مؤلفه كمترى به جاى تعـداد زيـادى صـفت فراهم مى كند. ميزان واريانس نسبى هر عامل نشاندهنده اهميت

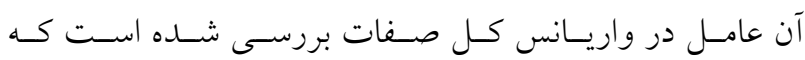
بهصورت درصد بيـان مسىشـود (ها). ايسن روش مسىتوانـد در تشخيص صفات بر اهميتتر در زمينه جداسازى نزادگَانهـاى مورد بررسى سودمند باشــ (YO). نتـايج حاصـل از تجزيـه بــه مؤلفههاى اصلى شامل مقادير ويزه، درصد واريانس توجيه شده و واريانس كل در جدول (ه) آورده شده اسـت. نتـايج حاصسله نشان داد كه r r متغير اوليه در قالب پِنج عامل اصـلى و مسـتقل

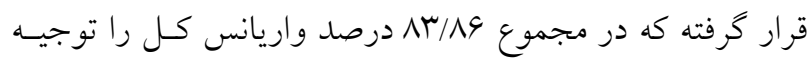
مى كنند. لازم به توضيح اسـت كـه سـه عامـل اول بـيش از 90 درصد از واريانس كل را توجيه مى كنند. صـفات كمّـى ميسوه از جمله ابعـاد و انــازه ميـوه، حجــم، درصــ كرويـت و ضـريب

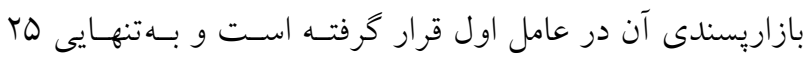
درصد از واريانس كل را توجيه كرد. شـاخص هــاى مربـوط بـهـ رنخ ميوه نيز در عامل دوم قرار گرفتهانــد. عامـل سـوم صـفات مربوط به pH قند كل و شاخص L رنخ بـود و اسـيديته ميـوه بهتنهايى در عامل جهارم قرار كرفت و دو صفت طول دم ميـوه و شاخص Hue رنخ در عامل ينجم قرار گرفتهاند. با توجـه بـهـ نتايج حاصله از تجزيه عاملى نزادكانهاى مورد مطالعه، به نظـر

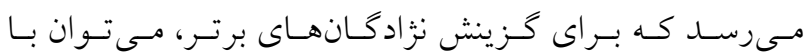
اندازهكيرى صفات مربوط به كميت ميوه بهجاى ارزيـابى تعــاد زيادى از صفات، به نتايج ارزشمند و قابل اطمينان رسيد. وجود 


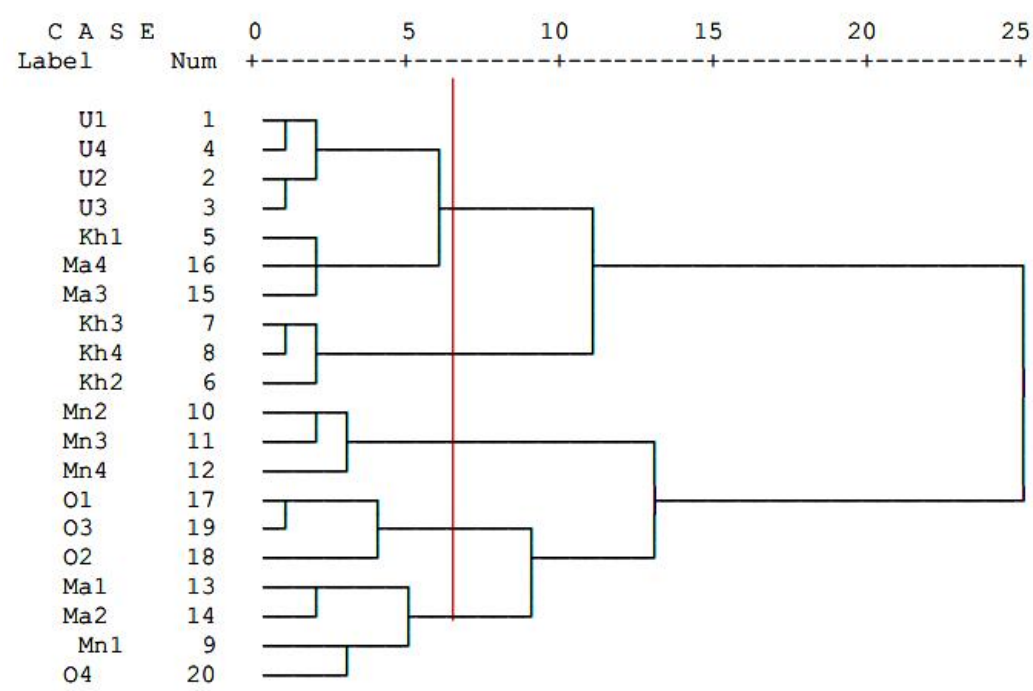

شكل ا. گروهبندى نزادكانهاى مورد مطالعه توتسفيد بر اساس روش وارد

نزادگـان سان از نظـر وزن ميــوه داراى بيشـترين ميــانخين بــود.

همجنين نتايج ارزيابى رنخ ميوه نشان داد كه بيشترين مقدار براى

شاخص L رنخ نيز مربوط به نزادگانهاى شهرستان خوى بـوده

كه نشان از شفافيت بــالاى ميـوههـا در ايـن منطقـهـ اسـت. نتـايج

بهدست آمده از اين مطالعه مىتواند براى اصلاحخران در توليــ و

اصلاح ارقامى كه توانايى عملكرد و بازاريسـندى بـالاترى داشـته

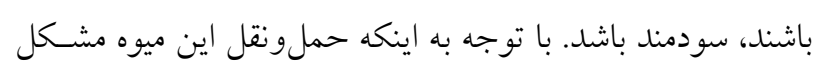

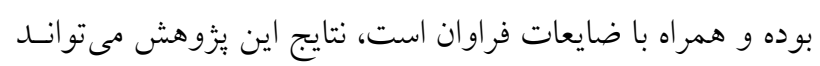

در طراحى مدلها و روشهاى بستهبندى، طراحى و بهينسهـازى

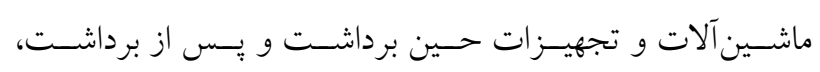

فراورى، جداسازى و بستهبندى ميوه توت بهمنظـور كمتـر كـردن

$$
\text { صدمات مكانيكى، ارزشمند و كاربردى باشد. }
$$

روش تجزيه خوشهاى دادهها نشان داد كه صـفات مورفولـوزيكى براى ارزيابى و شناسايى تنوع موجود در زرميلاسـم تـوت سـفيد

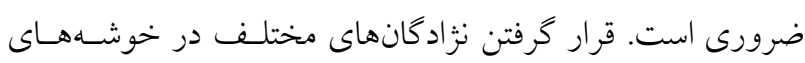
متفاوت بيانكر وجود تنوع بالا در بين نزادكانهاى مـورد بررسى ترى

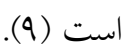
نتيجه گيرى نتايج بهدسـت آمـده از ايسن بـرزوهش در مجمـوع نشـان داد كـهـ

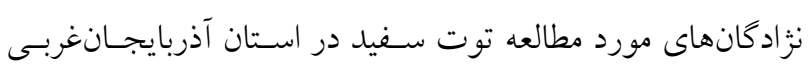
داراى تنوع زنتيكى نسبتاً خوبى بود كه ايسن امـر مسى توانــ مـورد

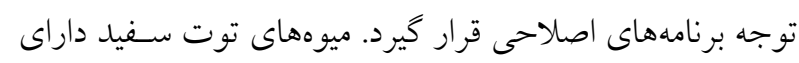

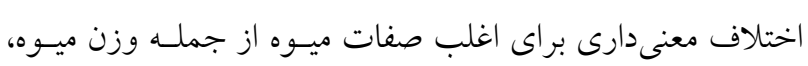

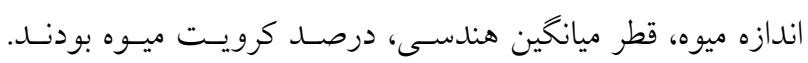

\section{منابع مورد استفاده}

1. Alabadan, B. A. 1996. Physical properties of selected biomaterials as related to their postharvest handling. In: Proceeding of the Nigerian Society of Agricultural Engineers Symposium. Nigeria. 18: 328-331.

2. Alizadeh, S. and H. Hassanpour. 2017. Evaluation of fruit morphological properties of some wild barberry (Beberis spp.) genotypes in West Azerbaijan. Iranian Journal of Horticultural Science 48: 27-37. (In Farsi).

3. Aljane, F. and N. Sdiri. 2016. Morphological, phytochemical and antioxidant characteristics of white (Morus alba 
L.), red (Morus rubra L.) and black (Morus nigra L.) mulberry fruits grown in arid regions of Tunisia. Journal of New Sciences 35(1): 187-192.

4. Asghari, M., R. Ebrahimi, B. Hosseinzadeh and D. Ghanbarian. 2017. Mulberry qualitative pramaters modelling in drying process using artificial neural networks. Iranian Journal of Biosystem Engineerning 48: 18-9. (In Farsi).

5. Asgharian Najaf Abadi, S., H. Ghasemzadeh and J. Hajiloo. 2015. Determination of some physical properties of strowberry fruit (Selva cultivar). Iranian Journal of Biosystem Engineerning 44: 1-8. (In Farsi).

6. Ayubnezhadghan, B. 2016. Investigation of physicochemical and antioxidant characteristics of some Medlar (Mespilas germanica L.) genotypes in East Azerbaijan province. MSc. Thesis. Urmia University. Urmia, Iran. (In Farsi).

7. Basiri, S. H. 2017. Determination of some of physico-chemical the properties and suitable storage time of concentrated mulberry in Khorasan region. Iranian Journal of Food Science and Technology 14(44): 175-186. (In Farsi).

8. Boubaya, A., M. Ben Salah, N. Marzzougui and A. Ferchichi. 2009. Pomological characterization of the mulberry tree (Morus spp.) in the south of Tunisia. Journal of Arid Land Studies 19(1): 157-159.

9. Dirili, S., H. Hassanpour and A. Farokhzad. 2018. Pomological characteristics of some hawthorn genotypes in West Azerbaijan province. Iranian Journal of Horticultural Science 48(3): 689-700. (In Farsi).

10. Ercisli., S. and E. Orhan. 2007. Chemical composition of white (Morus alba), red (Morus rubra) and black (Morus nigra) mulberry fruits. Food Chemistry 103: 1380-1384.

11. Erkan, M. and N. Selcuk. 2015. The effects of 1-MCP treatment on fruit quality of medlar fruit (Mespilus germanica L. cv. Istanbul) during long term storage in the pallifex storage system. Postharvest Biology and Tecgnology 100: 81-90.

12. Fakhraie Lahiji, M., R. Tabar, A. Fathi, Gh. Abadouz, M. Hajhasani, A. Farhadi, Gh. Khakizad, Z. Azizi, B. Samadi, M. Kiyani, A. Mirakhorli, N. Forumadi, J. Mozafari and R. Rafezli. 2016. Investigation genetic diversity mulberry fruits (Morus spp) with morphological properties in Iran. Agriculture Production 39(3): 12-17. (In Farsi).

13. Fattahi, J., Y. Hamidoghli, R. Fotouhi, M. Ghasemnejad and D. Bakhshi. 2011. Evaluation of physicochemical properties and antioxidant activity of the peel of different commercial citrus species. Journal of Horticulture Science 25(2): 211-217. (In Farsi).

14. Fattahi, J., E. Seyedghasemi and S. Madani. 2017. The effect of five rootstocks on physical, mechanical and chemical characteristics of 'Yashar' fruits -a new mandarin- during ripening stages. Journal of Plant Production Research 24(2): 109-123. (In Farsi).

15. Ghahreman, A. 1978. Flora Iran. University of Tehran Press, Tehran.

16. Hadadinejad, M., S. Qasemiomran and F. Azizmi Ahangari. 2015. Morphological diversity of blackberries in some regions in Mazandaran province. Iranian Journal of Horticultural Science 46: 333-343. (In Farsi).

17. Hepsag, F., O. Golge and I. Hayoglu. 2016. Effect of genotypes on chemical and physical properties of mulberry. Hacettepe Journal of Biology and Chemistry 44(3): 225-231.

18. Hernandez Munoz, P., E. Almenar, V. Del Valle, D. Velez and R. Gavara. 2008. Effect of chitosan coating with postharvest calcium treatment on strawberry quality during refrigerated storage. Food Chemistry 110(2): 428-435.

19. Jiang, Y. and W. Nie. 2015. Chemical properties in fruits of mulberry species from the xinjiang province of china. Food Chemistry 174: 460-466.

20. Karadeniz, T. and S. M. Sen. 1990. Morphological and pomological properties of pears grown in Tirebolu and Vicinity. Journal of the Faculty of Agriculture 1: 152-165.

21. Najafzadeh, R. and K. Arzani. 2016. Assessment of morphological, physiological and pomological variations in some of European pear (Pyrus communis L.) genotypes. Journal of Crop Production and Processing 6(19): 151-164. (In Farsi).

22. Nikkhah, E., M. Khayami and M. Heidari. 2009. Evaluation of nitric oxide scavenging activity of anthocyanins from Morus nigra L., strawberry (Fragaria ananassa) and Morus alba Var. Nigra extracts. Iranian Journal of Medicinal and Aromatic Plants 25(1): 120-128. (In Farsi).

23. Safi yari, H., H. Rahmanin, F. Salmani zade and A. Zommorodian. 2012. Some physical and mechanical properties of fruits persimmon khorramandi variety. Journal of Innovation in Science and Technology of Food Industry 5(4): 67-73. (In Farsi).

24. Samimi Akhijahani, H. and J. Khodaei. 2011. Some physical properties of strawberry (Kurdistan Variety). World Applied Sciences Journal 13 (2): 206-212. (In Farsi).

25. Sánchez-Salcedo, E., P. Mena, C. García-Viguera, J. Jose Martínez and F. Hernandez. 2015. Phytochemical evaluation of white (Morus alba L.) and black (Morus nigra L.) mulberry fruits, a starting point for the assessment of their beneficial properties. Journal of Functional Foods 12:399-480.

26. Tabatabaeefar, A. and A. Rajabipour. 2005. Modeling the mass of apples by geometrical attributes. Scientia Horticulturae 105: 373-382.

27. Yilmaz, K.U., Y. Zengin, S. Ercisli, E. Orhan, E. Yalcinkaya, O. Taner and A. Erdogan. 2009. Biodiversity, exositu conservation and characterization of cornelian cherry (Cornus mas L.) genotypes in Turkey. Biotechnology and Biotechnological Equipment 23(1): 1143-1149. 


\title{
Investigation of Physicochemical Characteristics and Fruit Color of Some White Mulberry (Morus alba) Genotypes in West Azerbaijan Province of Iran
}

\author{
S. Firoz barandozi ${ }^{1}$ and H. Hassanpour ${ }^{*}$
}

(Received: July 30-2018; Accepted: March 18-2019)

\begin{abstract}
White mulberry (Morus alba) belongs to the Moraceae family. The aim of this study is to evaluate some important physicochemical characteristics and fruit color of white mulberry grown in West Azarbaijan province of Iran. White mulberry fruits collected from five regions (Urmia, KHoy, Mahabad, Miyandoab and Oshnaviyeh) in West Azarbaijan province, were transferred to the laboratory and some properties such as fruit weight, fruit and leaf length and width, fruit color parameters, fruit volume and $\mathrm{pH}$ were measured. The results showed that the highest percentage of variation was observed in Hue and $\mathrm{a}^{*}$ traits, hence these traits had the highest diversity among the studied genotypes. The maximum and minimum fruit weight was observed in genotypes kh3 (4.24 g) and O3 $(0.71 \mathrm{~g})$, respectively. The fruit length had significant positive correlation with fruit thickness, volume and weight. The five main factors explained $83.86 \%$ of the total variance. Based on the cluster analysis, genotypes were divided into five main groups. In general, the results showed that physical properties of the fruit could be helpful for evaluation and identification of variation in white mulberry germplasm. These results could be valuable and practical in breeding programs and also designing appropriate models and packaging methods for white mulberry fruits.
\end{abstract}

Keywords: Cluster analysis, Correlation, Fruit Volume, Morphological properties

1,2. MSc. Student and Associate Professor, Respectively, Department of Horticulture, Faculty of Agriculture, Urmia University, Urmia, Iran.

*: Corresponding Author, Email: ha.hassanpour@urmia.ac.ir 